\section{REFERENCES}

1. Gogos A, Sbisa AM, Sun J, Gibbons A, Udawela M, Dean B. A role for estrogen in schizophrenia: clinical and preclinical findings. Int J Endocrinol. 2015;2015:615356.

2. Liao TL, Tzeng CR, Yu CL, Wang YP, Kao SH. Estrogen receptor beta in mitochondria: implications for mitochondrial bioenergetics and tumorigenesis. Ann N Y Acad Sci. 2015;1350:52-60.
3. Cuperfain AB, Zhang ZL, Kennedy JL, Gonçalves VF. The complex interaction of mitochondrial genetics and mitochondrial pathways in psychiatric disease. Mol Neuropsychiatry. 2018;4(1):52-69.

4. Verge B, Alonso Y, Valero J, Miralles C, Vilella E, Martorell L. Mitochondrial DNA (mtDNA) and schizophrenia. Eur Psychiatry. 2011;26(1):45-56.

5. Ventura-Clapier R, Moulin M, Piquereau J, Lemaire C, Mericskay M, Veksler V, et al. Mitochondria: a central target for sex differences in pathologies. Clin Sci. 2017;131 (9):803-22.

\title{
Vaccines to treat opioid use disorders and to reduce opioid overdoses
}

\author{
Carly Baehr ${ }^{1,2}$ and Marco Pravetoni ${ }^{2,3}$ \\ Neuropsychopharmacology (2019) 44:217-218; https://doi.org/10.1038/s41386-018-0197-3
}

As the incidence of opioid-related fatal overdoses continues to rise in the United States, new therapeutic strategies for opioid use disorders (OUD) are needed. One proposed solution is active immunization with anti-opioid conjugate vaccines, which selectively reduce the effects of their target opioid through production of drug-specific antibodies. As opposed to pharmacotherapies (e.g., methadone, buprenorphine, and naltrexone) targeting opioid receptors in the brain, opioid-specific antibodies operate through a pharmacokinetic mechanism by sequestering the target opioid in serum and reducing its distribution to the brain. Anti-opioid vaccines could provide safe and cost-effective interventions that offer several advantages over current small molecule medications: long-lasting protection that reduces the burden of compliance; no abuse liability or risk of diversion; and due to their selectivity, vaccines do not interfere with endogenous opioids, or with nontarget opioids prescribed for pain management or for treatment of OUD. To improve clinical outcome, vaccines could be used in combination with other medications for OUD.

Extensive preclinical studies have identified a series of lead vaccines selectively targeting heroin, oxycodone, hydrocodone, or fentanyl (e.g., [1-3]). Anti-opioid vaccines effectively reduce distribution of the target opioid to the brain, and reduce opioidinduced behavior, including drug self-administration, in mice, rats, or nonhuman primates. Notably, vaccine efficacy in reducing opioid distribution to the brain depends on the target opioid, its dose, and route of exposure [2], highlighting the need to consider variables such as patterns of drug use in study design of clinical trials. Supporting a role for vaccines in overdose prevention, vaccination reduces opioid-induced respiratory depression and bradycardia, two significant factors in overdose-related fatalities [4]. Additionally, anti-opioid vaccines do not interfere with naloxone reversal of opioid toxicity [4] and improve survival following a lethal heroin dose [5].

Clinical evaluation of first-generation nicotine and cocaine vaccines has shown that only a subset of immunized subjects produced levels of drug-specific antibodies sufficient for efficacy. Therefore, it is critical to optimize vaccine formulations to maximize efficacy, to understand the immunological mechanisms underlying effective immune responses, and to identify biomarkers predictive of individual variability. Multiple studies have focused on vaccine design, including optimization of hapten and linker chemistry, choice of carrier protein and adjuvant, and development of novel carriers and delivery platforms. Effective formulations of vaccines against heroin have included the TLR9 agonist CpG [5] and liposomes containing the TLR4 agonist monophosphoryl lipid A [3]. The efficacy of an oxycodone vaccine was enhanced by shifting IgG subclass distribution through inhibition of interleukin-4 signaling, both indicating a pharmacological target for vaccine development, and granting insight into mechanisms underlying vaccine efficacy [6]. Additionally, the pre-immunization frequency of hapten-specific B cell population subsets correlated with vaccine efficacy, suggesting that subjects likely to generate clinically effective opioid-specific antibody responses could be identified prior to vaccination [7]. Accelerating the translation of vaccines for OUD will benefit from rational design of more effective vaccine components, development of clinically viable formulations, and biomarkers supporting patient stratification.

Mounting preclinical data provide proof of selectivity and efficacy for anti-opioid vaccines, demonstrating their potential to treat OUD and reduce incidence of opioid overdoses. Testing these vaccines in clinical trials is warranted.

\section{ACKNOWLEDGEMENTS}

This work is supported by a Hennepin Healthcare Research Institute award (M.P.), and by the NIH under grants U01 DA038876 (M.P.), R01 DA041730 (M.P.), and T32DA007097 (C.B.).Competing interests: M.P. is the inventor of "Cytokine Signaling Immunomodulators and Methods," International Application No. PCT/US2017/031907 filed on May 10, 2017. C.B. declares no competing interests.

Publisher's note: Springer Nature remains neutral with regard to jurisdictional claims in published maps and institutional affiliations.

\footnotetext{
${ }^{1}$ Department of Veterinary Population Medicine, University of Minnesota, St. Paul, MN, USA; ${ }^{2}$ Hennepin Healthcare Research Institute (formerly Minneapolis Medical Research Foundation), Minneapolis, MN, USA and ${ }^{3}$ Departments of Medicine and Pharmacology, Center for Immunology, University of Minnesota, Minneapolis, MN, USA

Correspondence: Marco Pravetoni (prave001@umn.edu)
}

Published online: 12 September 2018 


\section{REFERENCES}

1. Bremer PT, Kimishima A, Schlosburg JE, Zhou B, Collins KC, Janda KD. Combatting synthetic designer opioids: a conjugate vaccine ablates lethal doses of fentanyl class drugs. Angew Chem Int Ed Engl. 2016;55:3772-5.

2. Raleigh MD, Laudenbach M, Baruffaldi F, Peterson SJ, Roslawski MJ, Birnbaum AK, et al. Opioid dose- and route-dependent efficacy of oxycodone and heroin vaccines in rats. J Pharmacol Exp Ther. 2018;365:346-53.

3. Sulima A, Jalah R, Antoline JFG, Torres OB, Imler GH, Deschamps JR, et al. A stable heroin analogue that can serve as a vaccine hapten to induce antibodies that block the effects of heroin and its metabolites in rodents and that cross-react immunologically with related drugs of abuse. J Med Chem. 2018;61:329-43.

4. Raleigh MD, Peterson SJ, Laudenbach M, Baruffaldi F, Carroll FI, Comer SD, et al. Safety and efficacy of an oxycodone vaccine: addressing some of the unique considerations posed by opioid abuse. PLoS One. 2017;12:e0184876.
5. Hwang CS, Bremer PT, Wenthur CJ, Ho SO, Chiang S, Ellis B, et al. Enhancing efficacy and stability of an antiheroin vaccine: examination of antinociception, opioid binding profile, and lethality. Mol Pharm. 2018; 15:1062-72.

6. Laudenbach M, Baruffaldi F, Robinson C, Carter P, Seelig D, Baehr C, et al. Blocking interleukin-4 enhances efficacy of vaccines for treatment of opioid abuse and prevention of opioid overdose. Sci Rep. 2018;8:5508.

7. Laudenbach M, Baruffaldi F, Vervacke JS, Distefano MD, Titcombe PJ, Mueller DL, et al. The frequency of naive and early-activated hapten-specific $B$ cell subsets dictates the efficacy of a therapeutic vaccine against prescription opioid abuse. J Immunol. 2015;194:5926-36.

\title{
Regulation of raphe serotonin neurons by serotonin 1A and 2B receptors
}

\author{
Arnauld Belmer ${ }^{1,2,3,4}$ and Luc Maroteaux (iD) ${ }^{1,2,3}$ \\ Neuropsychopharmacology (2019) 44:218-219; https://doi.org/10.1038/s41386-018-0214-6
}

Several lines of evidence implicate serotonin (5-hydroxytryptamine, 5-HT) in the etiology of mood disorders, including major depressive disorders. Serotonergic neurons have long been recognized as key contributors to the regulation of mood and anxiety as the main target of serotonin selective reuptake inhibitor (SSRI) antidepressants. The therapeutic effects of SSRIs are initially triggered by blockade of the serotonin transporter SERT increasing local extracellular serotonin. Serotonin neurotransmission is tightly regulated by autoreceptors (serotonin receptors expressed by serotonin neurons) known to act through negative feedback inhibition at the cell bodies (5- $\mathrm{HT}_{1 \mathrm{~A}}$ receptors) of the raphe nuclei or at the axon terminals (5- $\mathrm{HT}_{1 \mathrm{~B}}$ receptors). Beneficial SSRI effects rely on long-term adaptations that are, at least partially, ascribed to a selective desensitization of somatodendritic $5-\mathrm{HT}_{1 \mathrm{~A}}$ autoreceptors [1].

A positive regulation of serotonergic neurons by $5-\mathrm{HT}_{2 \mathrm{~B}}$ receptors has been detected in mice. Local agonist-stimulation of $5-\mathrm{HT}_{2 \mathrm{~B}}$ receptors in dorsal raphe nuclei increased extracellular serotonin suggesting a functional role of this receptor within serotonergic neurons [2]. Expression of 5- $\mathrm{HT}_{2 \mathrm{~B}}$ receptors has been detected in subset of serotonergic neurons albeit at low levels [3]. Both acute and long-term behavioral and neurogenic effects of SSRIs are abolished in mice knockout for $5-\mathrm{HT}_{2 \mathrm{~B}}$ receptor gene, $\left(\mathrm{Htr} 2 \mathrm{~b}^{-1-}\right)$ or after exposure to selective $5-\mathrm{HT}_{2 \mathrm{~B}}$-receptor antagonists. Conversely, chronic stimulation of $5-\mathrm{HT}_{2 \mathrm{~B}}$ receptors by selective agonists mimicked chronic SSRI actions on behavior and hippocampal neurogenesis, which were abolished in $\mathrm{Htr} 2 \mathrm{~b}^{-/-}$ mice [3]. Comparable lack of SSRI effects was recently reported in mice knockout for $5-\mathrm{HT}_{2 \mathrm{~B}}$ receptors only in serotonergic neurons (Htr2b $b^{5-H T K O}$ mice) in which dorsal raphe serotonin neurons displayed a reduced firing frequency, and a stronger hypothermic effect following $5-\mathrm{HT}_{1 \mathrm{~A}}$-autoreceptor stimulation [4]. Cell autonomous effects were confirmed by the increased excitability of serotonergic neurons observed upon raphe-selective $5-\mathrm{HT}_{2 \mathrm{~B}^{-}}$ receptor overexpression. Correlative findings have been described in humans, in which expression of $5-\mathrm{HT}_{2 \mathrm{~B}}$ receptors can be found in brain stem and a loss-of-function polymorphism of $5-\mathrm{HT}_{2 \mathrm{~B}}$ receptors has been associated with serotonin-dependent phenotypes, including increased impulsivity and suicidality [5].

Serotonin released within raphe nuclei is known to induce feedback inhibition of serotonergic neuron firing activity by stimulating dendritic $5-\mathrm{HT}_{1 \mathrm{~A}}$ negative autoreceptors. Unlike soma and terminals, the dendritic serotonin release is independent of action potentials, relies on L-type $\mathrm{Ca} 2+$ channels, can be induced by NMDA, and displays distinct sensitivity to the SSRI antidepressants [6]. Dendritic serotonin release, and hence $5-\mathrm{HT}_{1 \mathrm{~A}}$ receptormediated autoinhibition, is thus engaged by excitatory glutamatergic inputs to the dorsal raphe, via locally triggered calcium influx, rather than by neuronal firing. The unique control of dendritic serotonin release has important implications for the antidepressant action of SSRIs. The lack of $5-\mathrm{HT}_{2 \mathrm{~B}}$ receptor in serotonergic neurons is associated with a higher $5-\mathrm{HT}_{1 \mathrm{~A}}$-autoreceptor reactivity and thus a lower activity of these neurons [4]. The excess of inhibitory control exerted by $5-\mathrm{HT}_{1 \mathrm{~A}}$ receptors in $H t r 2 b^{5-H T K O}$ mice may thus explain the lack of response to chronic SSRI in these mice.

The serotonergic tone of raphe neurons and thus the SSRI therapeutic effects likely results from the opposite control exerted by $5-\mathrm{HT}_{1 \mathrm{~A}}$ and $5-\mathrm{HT}_{2 \mathrm{~B}}$ receptors via a mechanism that remains to be described.

\section{ACKNOWLEGMENT}

This work has been supported by funds from the Centre National de la Recherche Scientifique, the Institut National de la Santé et de la Recherche Médicale, the Sorbonne Universités, and by grants from the Fondation pour la Recherche sur le Cerveau, the Fondation de France, the Région Ile-de-France, the Fondation pour la

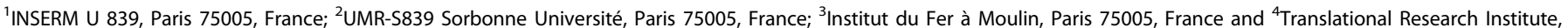
Queensland University of Technology, Brisbane, QLD 4059, Australia

Correspondence: Luc Maroteaux (luc.maroteaux@upmc.fr)

Published online: 25 September 2018 